\title{
Kinetid structure in sponge choanocytes of Spongillida in the light of evolutionary relationships within Demospongiae
}

\author{
IGOR R. POZDNYAKOV ${ }^{1 *}$, AGNIYA M. SOKOLOVA ${ }^{2,3}$, ALEXANDER V. ERESKOVSKY $^{4,5}$ and \\ SERGEY A. KARPOV ${ }^{1,6}$ \\ ${ }^{1}$ Department of Invertebrate Zoology, Biological Faculty, St. Petersburg State University, \\ Universitetskaya nab. 7/9, St. Petersburg, 199034, Russia \\ ${ }^{2}$ A. N. Severtzov Institute of Ecology and Evolution, Leninskij prosp. 33, Moscow, 119071, Russia \\ ${ }^{3}$ N. K. Koltzov Institute of Developmental Biology, Russian Academy of Sciences, Vavilova street 26, \\ Moscow, 119334, Russia \\ ${ }^{4}$ Aix Marseille University, Avignon Université, CNRS, IRD, IMBE, Marseille, France \\ ${ }^{5}$ Department of Embryology, Biological Faculty, St. Petersburg State University, Universitetskaya nab. \\ 7/9, St. Petersburg, 199034, Russia \\ ${ }^{6}$ Zoological Institute of Russian Academy of Science, Universitetskaya nab. 1, St. Petersburg, 199034, \\ Russia
}

Received 31 August 2016; revised 2 December 2017; accepted for publication 12 December 2017

\begin{abstract}
With the advent of molecular phylogenetics, the morphology-based classification of Porifera has been cardinally changed. However, the relationships between some clusters of Demospongiae, the most diverse sponge class, remain uncertain. An analysis of sponge cell ultrastructures, in particular the flagellar apparatus (kinetid) of choanocytes, may help clarify the evolutionary links in Demospongiae. We studied the kinetid structure of the sponges Spongilla lacustris, Ephydatia fluviatilis and Lubomirskia baikalensis, which belong to the recently established order Spongillida (Heteroscleromorpha). In these sponges, the kinetid of the choanocytes have a uniform structure, consisting of a single kinetosome (without centriole) encircled with a ring of electron-dense bodies producing lateral microtubules. The flagellar transition zone contains a transverse plate with an axosome and a coiled filament. This type of kinetid is similar to that of Haplosclerida representatives, whose morphologic similarities with Spongillida representatives were still not explained. We also discussed the nuclear location in the choanocyte (basal or apical), which correlates to the kinetid structure in Demospongiae. Only three types of flagellar apparatus have been found in Demospongiae up to now, implying that the kinetid is one of the most conservative structures in sponge evolution.
\end{abstract}

ADDITIONAL KEYWORDS: choanocyte - Demospongiae - Ephydatia fluviatilis - Heteroscleromorpha kinetid - Lubomirskia baikalensis - phylogeny - Porifera - sponges - Spongilla lacustris.

\section{INTRODUCTION}

Porifera is undergoing a major systematic reassessment and the evolutionary history of Demospongiae, the richest sponge group, has proved to be a particularly complex problem. Their limited morphological characters, combined with the diversity of interpretations, have resulted in numerous reconstructions of demospongian classification. There have been several variants of

*Corresponding author. E-mail: d_igor_po@yahoo.com the demospongian phylogenetic tree based on morphological features (e.g. Lévi, 1953; Bergquist, 1978). The authors of the fundamental work 'Systema Porifera' (Hooper \& van Soest, 2002) proposed a new system for the phylum Porifera based on morphological cladistic analysis. They revised many traditional approaches to poriferan phylogeny and classification and confirmed in general the splitting of Demospongiae into the three subclasses (Homoscleromorpha, Tetractinomorpha and Ceractinomorpha) introduced by Lévi (1953), but the division into orders was largely reconsidered. For example, the previously independent orders Axinellida 
and Halichondriida were considered closely related and united into a single order: Halichondriida (Hooper $\&$ van Soest, 2002).

Borchiellini et al. (2004) constructed a molecular tree of Porifera based on $18 \mathrm{~S}$ and some domains of 28S rDNA sequences and initiated a new direction for evolutionary studies of sponges. Since then, additional molecular data have been accumulated and summarized (Morrow et al., 2012, 2013; Wörheide et al., 2012; Redmond et al., 2013) and a new version of demospongian systematics has been proposed (Morrow \& Cárdenas, 2015). This new system partially reverts to earlier classifications. For example, the orders Axinellida and Tetractinellida are re-established according to Bergquist (1978). However, some other relationships between orders, subclasses and classes appear for the first time. The most unexpected alterations to Demospongiae systematics are: (1) the former subclass Homoscleromorpha does not belong to Demospongiae (Gazave et al., 2012), (2) the spiculeless sponges form a separate branch of Demospongiae, splitting this taxon into two groups: with and without spicules respectively, (3) among the spicular sponges, the order Haplosclerida is a sister group to the rest, (4) reclassification of the former freshwater haplosclerids to a new order: Spongillida.

The position of spicule-less demosponges and Haplosclerida has been generally accepted, whereas for Spongillida, another tree topology has been suggested (Sperling, Peterson \& Pisani, 2009; Hill et al., 2013). Hill and Sperling with their coworkers asserted that Spongillida is related to Haplosclerida, as had been claimed in previous versions of the phylogeny (Bergquist, 1978; Manconi \& Pronzato, 2002). This also corresponds to morphological data: these orders share skeletal morphotraits and the ability to produce gemmules (Manconi \& Pronzato, 2002, 2015). However, Morrow \& Cárdenas (2015) considered this relationship not well supported and an artefact of undersampling.

Recent large multigene comparison (Simion et al., 2017) has also showed Haplosclerida and Spongillida to be distantly related, but another recent study (Schuster et al., 2017) has supported the kinship of these two orders again.

Therefore, the phylogenetic relationship between Spongillida and Haplosclerida requires careful consideration and explanation based on a complex approach taking into account all possible characters. Determining the phylogenetic significance of additional morphological characters may be useful in this regard. Previously, we discussed the usability of the flagellar apparatus (kinetid) structure of choanocytes as a phylogenetic marker (Pozdnyakov \& Karpov, 2013, 2015, 2016). We demonstrated that kinetid structure differs between representatives of different sponge orders and that there is agreement between the topology of the molecular phylogenetic tree of sponges and the positions of different choanocyte kinetid types on this tree. Therefore, we can determine kinetid evolutionary history based on molecular tree analysis. Additionally, the kinetid structure possibly has characters that can be used as the morphological confirmation for a molecular tree.

In this paper, we present a detailed description of the kinetid structure of choanocytes in two species: Spongilla lacustris (Linnaeus, 1759) and Ephydatia fluviatilis (Linnaeus, 1759) (Spongillida, Spongillidae), and less detailed data on Lubomirskia baikalensis (Pallas, 1776) (Spongillida, Lubomirskiidae). All these sponges belong to the newly established order Spongillida with newly proposed phylogenetic relationships (Morrow \& Cárdenas, 2015). Therefore, it is especially interesting to provide additional morphological support for such establishment and to compare features of the new order with other taxa in Demospongiae.

\section{MATERIAL AND METHODS}

The specimens of $S$. lacustris were grown in laboratory culture from gemmules collected from a pond near Saint Petersburg in September 2013. They were cultivated in Petri dishes filled to 2/3 of their volume with tap water originating from the Neva River. The gemmules hatched on the second day of cultivation and after about 3 days, the oscular tubes of the young sponges formed. For transmission electron microscopy (TEM), we used approximately 8-day-old sponges with well-developed oscular tubes. They grew and began to acquire a green coloration. For prefixation, $1 \mathrm{~mL}$ of $1 \%$ osmium tetroxide in cacodylate buffer $\left(0.1 \mathrm{~mol} \mathrm{l}^{-1}, \mathrm{pH} 7.4\right)$ was added to $3 \mathrm{~mL}$ of water containing a sponge fragment. Next, $4 \mathrm{~mL}$ of $4 \%$ glutaraldehyde in the same buffer was added and the sponge fragment was kept in this mixture for $15 \mathrm{~min}$ on ice in the dark. Then, the fixative mixture was replaced with $2 \%$ glutaraldehyde for $1 \mathrm{~h}$ on ice. Afterwards, samples were rinsed twice in the buffer and postfixed in $1 \%$ osmium tetroxide for $1 \mathrm{~h}$ at room temperature. The samples were then washed twice for $10 \mathrm{~min}$ in the same buffer, dehydrated in a graded ethanol series and embedded in Epon-Araldite resin.

After polymerization, the resin blocks with sponge fragments were trimmed and treated with $10 \%$ hydrofluoric acid for $5 \mathrm{~min}$ to remove siliceous skeletal elements. Ultrathin sections $(60 \mathrm{~nm})$ were cut with a Leica EM UC6 ultramicrotome using a glass knife. The sections were double stained in uranyl acetate (15 $\mathrm{min})$ and subsequently lead citrate $(3 \mathrm{~min})$ and were observed in a JEM 1400 electron microscope equipped with an Olympus Veleta digital camera.

The specimens of L. baikalensis were collected from Lake Baikal near Cape Listvenichny at $12 \mathrm{~m}$ depth 
by SCUBA in March 2015. Fixation for TEM was performed according to the following protocol: pre-fixation in $1 \% \mathrm{OsO}_{4}$ for $10 \mathrm{~min}$, rinsing in cacodylate buffer (30 mM, pH 7.9) for $10 \mathrm{~min}$, fixation in $1.5 \%$ glutaraldehyde solution in cacodylate buffer for $1 \mathrm{~h}$, rinsing in cacodylate buffer for $30 \mathrm{~min}$, post-fixation in $1 \%$ $\mathrm{OsO}_{4}$ solution in cacodylate buffer for $2 \mathrm{~h}$. Afterwards the post-fixation samples were washed in filtered Baikalian water, desilicated in $5 \% \mathrm{HF}$ at $6{ }^{\circ} \mathrm{C}$ during the night, dehydrated in a graded ethanol series and embedded in Araldite resin. Ultrathin sections (60$80 \mathrm{~nm}$ ) were cut with a RMC PowerTome XL ultramicrotome equipped with a diamond knife Drukkert $45^{\circ}$. After staining, the sections were examined with Zeiss-1000 and JEOL JEM 1400 electron microscopes.

Electron micrographs of $E$. fluviatilis from S. A. Karpov's personal collection were re-examined with particular attention to the kinetid structure. Preparation protocols for this material were published earlier (Karpov \& Efremova, 1994).

\section{RESULTS}

\section{KINETID STRUCTURE OF S. LACUSTRIS}

Choanocytes of $S$. lacustris usually have approximately equal dimensions in the apical-basal direction and from side to side, and look square in longitudinal sections with long microvilli at the collar. The nucleus occupies a basal position in the cell and has no connection with the flagellar apparatus (Fig. 1A, B).

The flagellum of $S$. lacustris has a typical eukaryotic organization $(9+2$ axoneme $)$ and emerges from a small protrusion on cell surface in the centre of the collar filled with a thick layer of loose glycocalyx composed of densely branching fibres (Fig. 1A, B). The surface of the flagellum bears two or three longitudinal vanes (Fig. 1B).

The transition zone of the flagellum is short: the proximal ends of the central microtubules are located nearly at the level of the cell surface (Fig. 2B, C). The central microtubules arise from the prominent axosome in the centre of a transversal plate (Fig. 2B, C, $\mathrm{G}, \mathrm{J})$. An axosome also produces several filaments in different directions (Fig. 2B, G, H).

A delicate thread-like circular filament adheres to the inner surface of the nine peripheral doublets and coils around the proximal end of the central tubules of the axosome (Fig. 3A, B). We believe it is a coiled fibre because no micrographs of transverse sections have demonstrated a complete circle.

The kinetosome has a typical structure of nine microtubular triplets (Fig. 3D-H). It is located inside the protrusion from which the flagellum emerges. Nine transitional fibres (alar sheets), about $100 \mathrm{~nm}$ long, project radially from the kinetosome and contact the cell membrane (Fig. 3C, H, I). Points of attachment are marked by electron-dense granules.

Transverse and longitudinal sections of the kinetosome show the presence of electron-dense bodies (satellites) on the kinetosomal surface (Figs 2C-J, 3D-H, J-T). Transverse sections demonstrate that the satellites are not separate from each other but merge into a ring (Fig. 3J, K). The comparison of longitudinal and transverse sections shows that the ring is probably incomplete, wavy and has variable thickness (Figs 2C-J, 3D-T).

The satellites produce single microtubules radiating laterally at various angles (Figs $2 \mathrm{C}-\mathrm{H}, 3 \mathrm{E}-\mathrm{H}, \mathrm{J}-\mathrm{N}$, $\mathrm{P}-\mathrm{T}, 4 \mathrm{~A}-\mathrm{E}$ ). Additional microtubular singlets arise directly from the proximal end of the kinetosome in
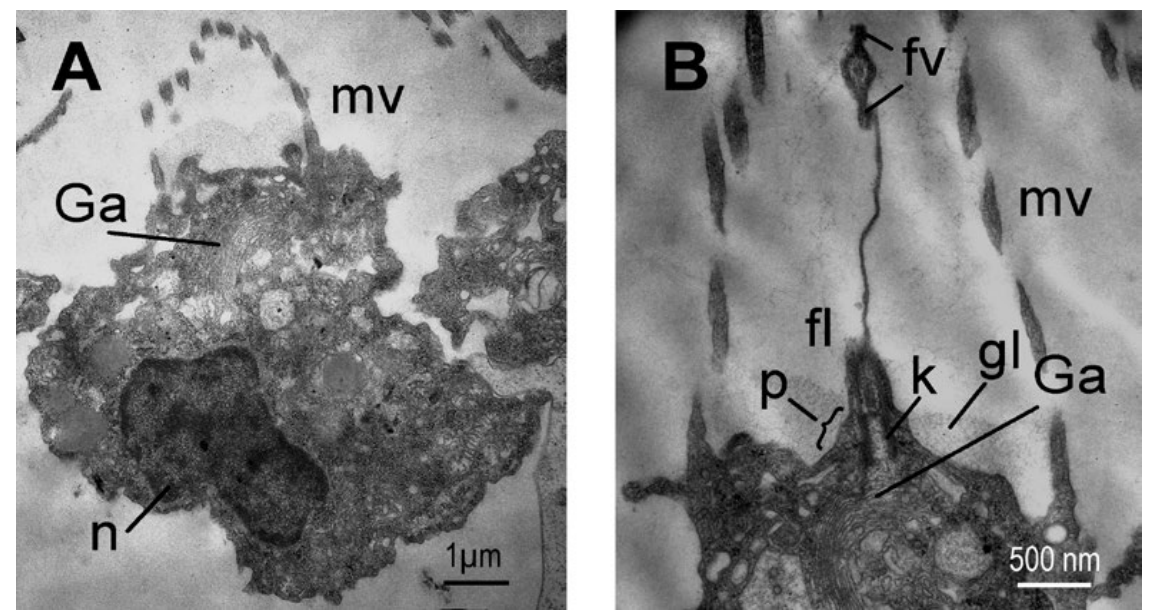

Figure 1. General view of a choanocyte of Spongilla lacustris in longitudinal section. A, whole cell. B, flagellar apparatus. Abbreviations: fl, flagellum; fv, flagellar vanes; Ga, Golgi apparatus; gl, glycocalix; k, kinetosome; mv, microvilli; n, nucleus; $\mathrm{p}$, protrusion at the base of flagellum. 

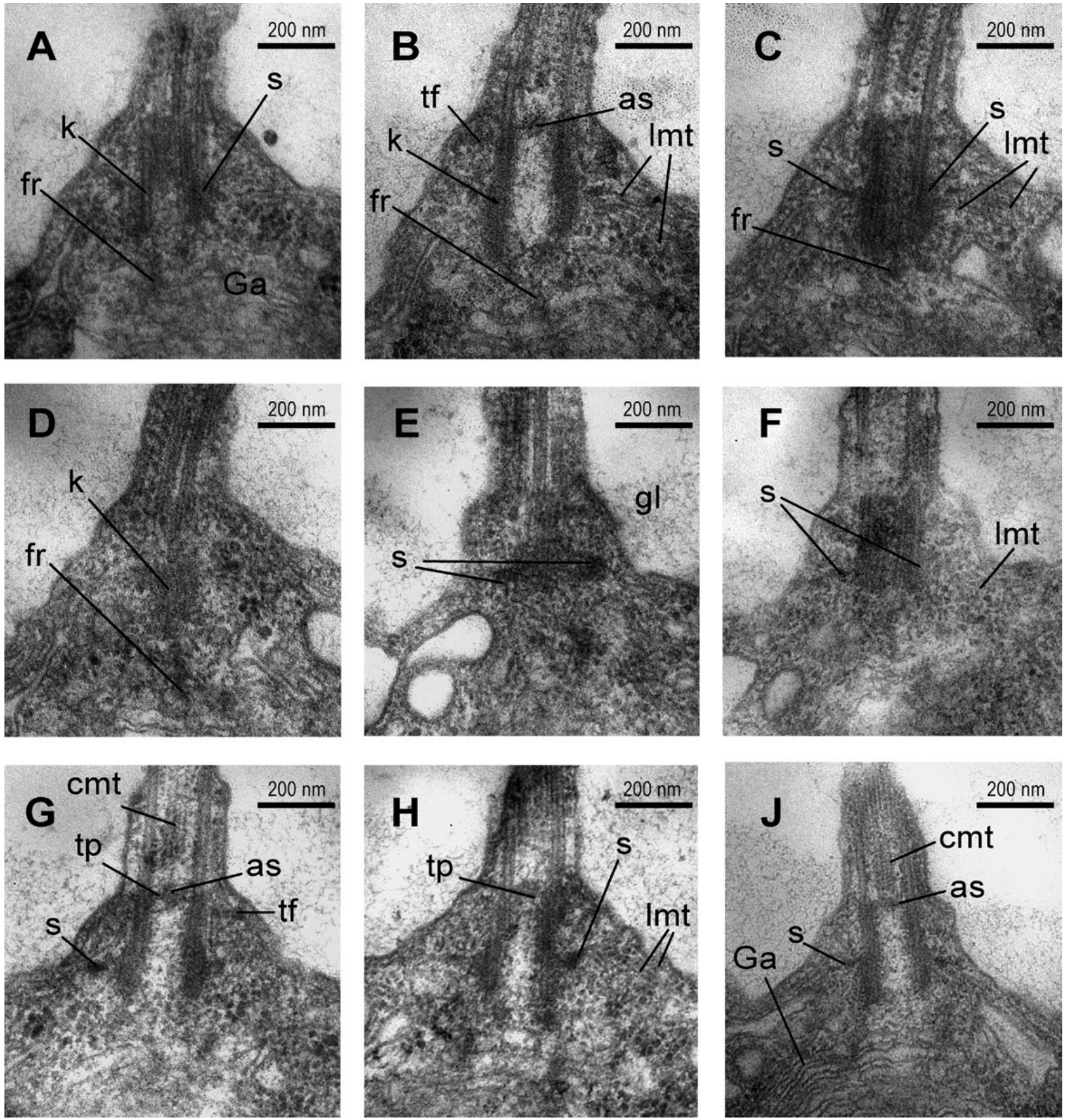

Figure 2. Series of longitudinal sections of Spongilla lacustris flagellar apparatus. A-D, the series of consecutive sections through the kinetosome. E-H, the series of consecutive sections through the kinetosome of another choanocyte. J, the section through the longitudinal axis of the kinetosome of one more choanocyte. Abbreviations: as, axosome; cmt, central microtubules; fr, fibrillar root; Ga, Golgi apparatus; gl, glycocalix; k, kinetosome; lmt, lateral microtubules; s, satellite; tf, transition fiber; tp, transverse plate; usm, unstructured material.

different directions (Fig. 4A, B, D). Some of the microtubules pass to the plasma membrane and underlie it for some distance (Fig. 4A, D, E).

The kinetosome of $S$. lacustris has short fibrillar roots that descend from the proximal ends of the triplets in the cytoplasm (Figs 2A-D, 3H, L). The Golgi complex is located below the kinetosome (Fig. 1A, B).

We found no traces of a permanent centriole in the majority of the complete serial sections of kinetids (Fig. 2A-H, 3A-H). However, in some series, 

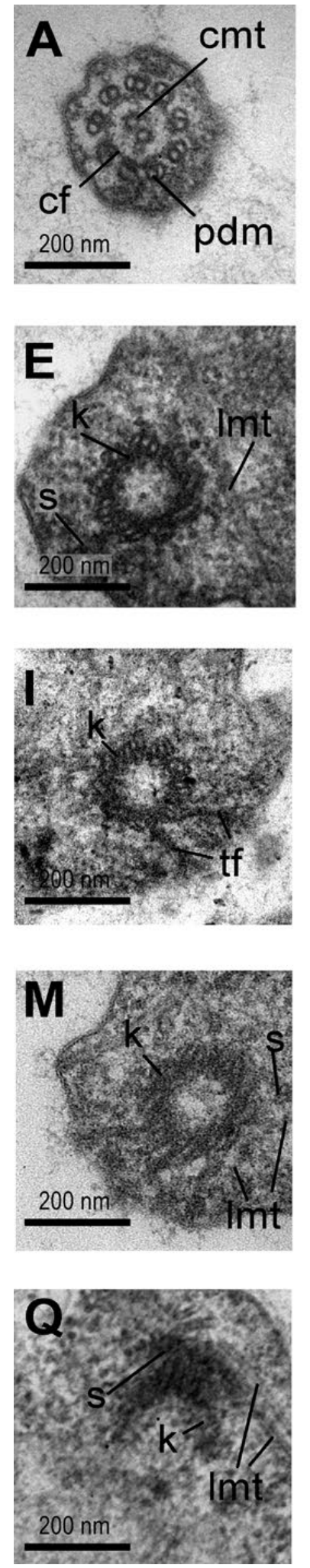
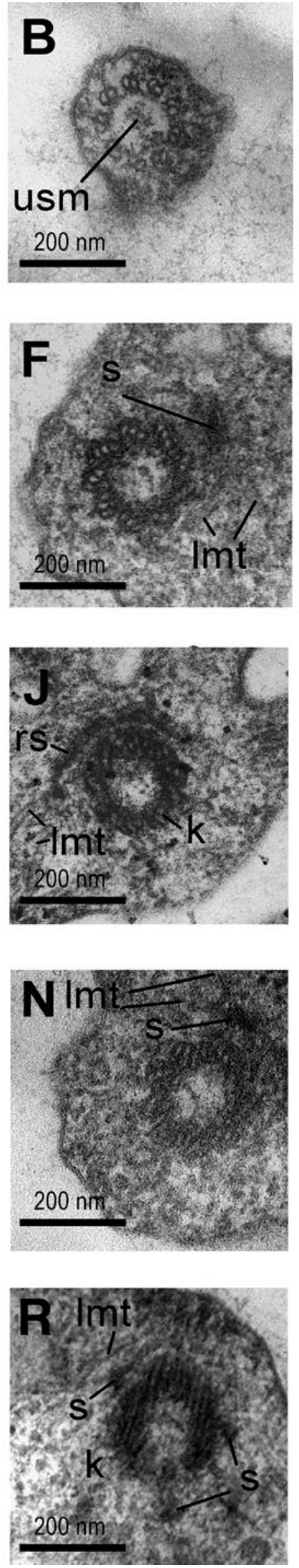
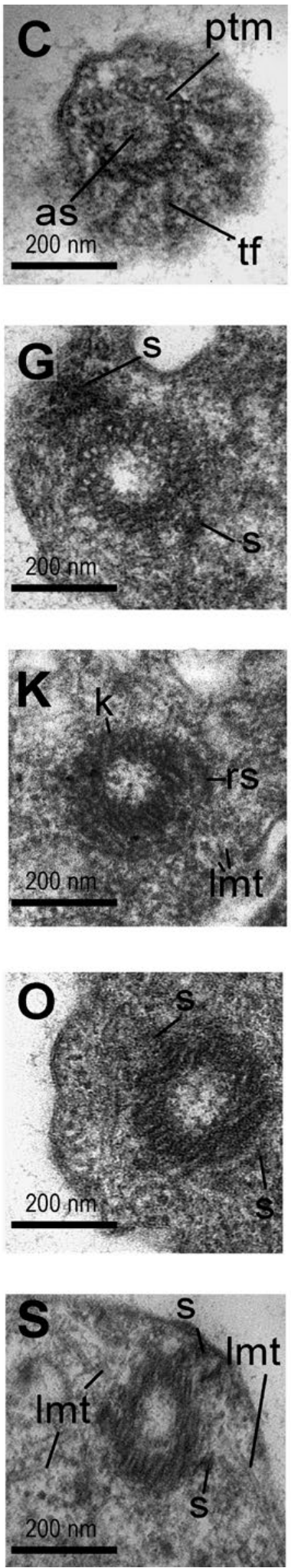
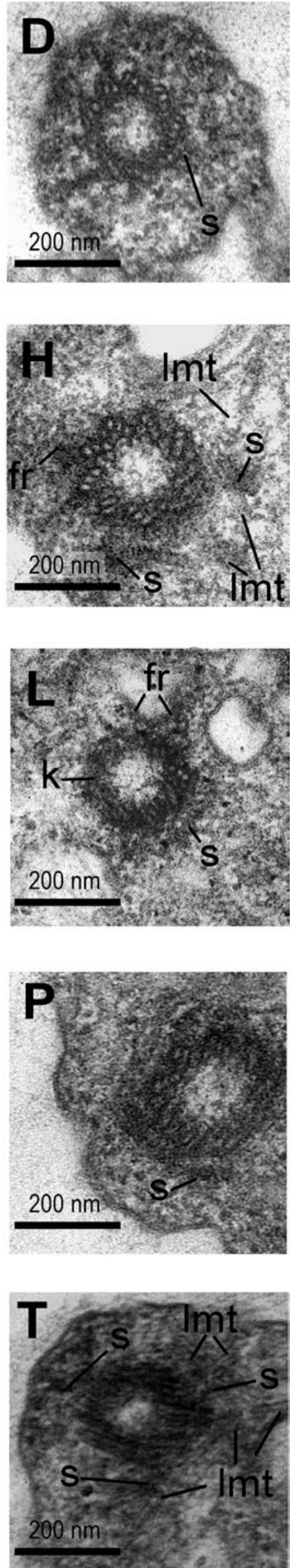

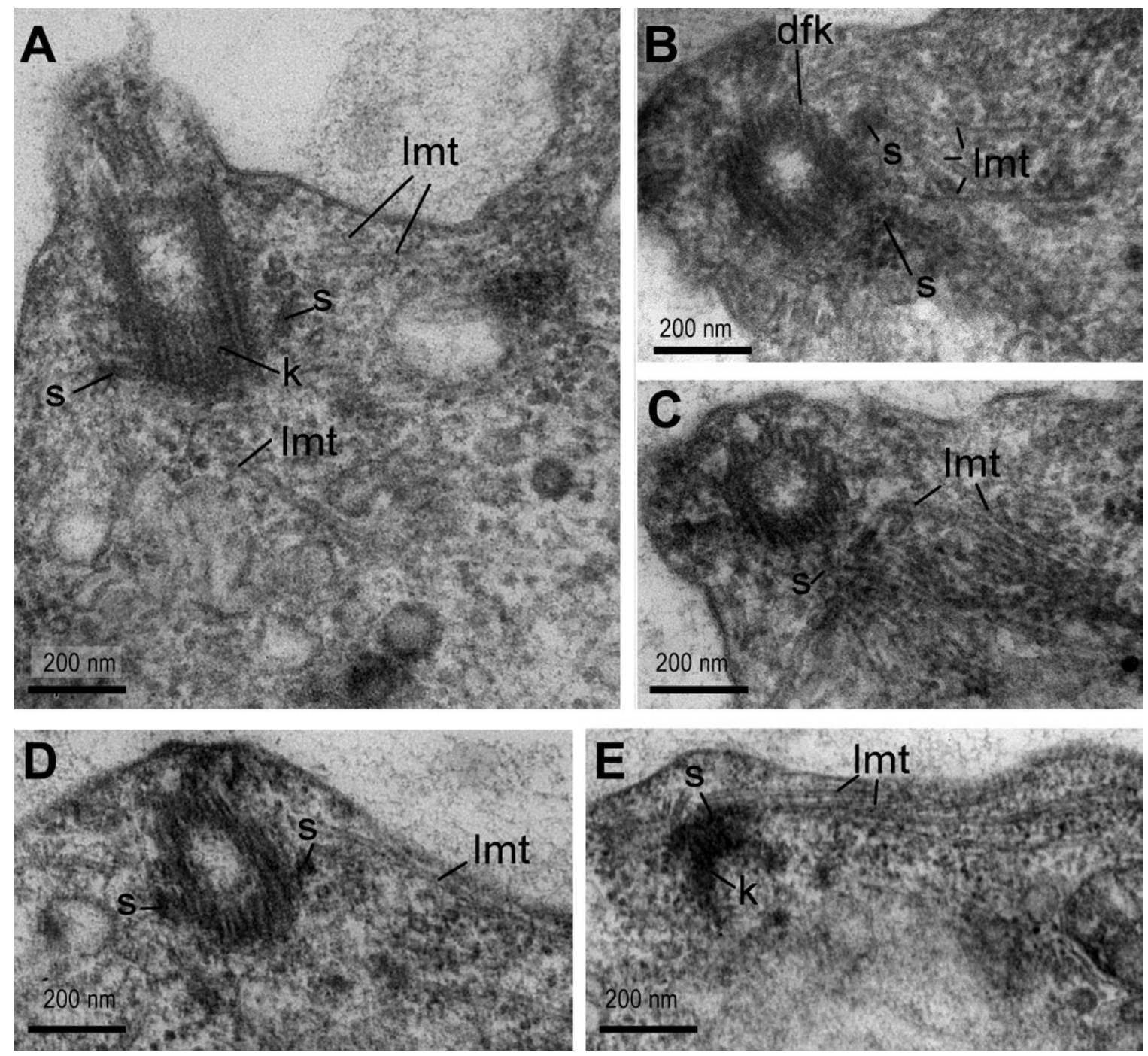

Figure 4. Patterns of lateral microtubules running from the MTOCs in the kinetid of Spongilla lacustris. A, longitudinal section through the kinetosome. B, C, two sections from a transverse series through the kinetosome from distal to proximal direction of one choanocyte. D, E, two sections from a transverse series through the kinetosome from proximal to distal direction of another choanocyte. Abbreviations: dfk, microtubules starting directly from kinetosome; k, kinetosome; lmt, lateral microtubules; s, satellite.

centriole-like bodies were present (Fig. 5A, B). At the same time, choanocytes without the nuclear envelope around the chromatin associated with microtubules (Fig. $5 \mathrm{C}-\mathrm{H}$ ) have been found in some sections. The centriole-like body is located near the kinetosome at the stage of a disordered nuclear envelope (Fig. 5E, F).
The centriole-like bodies were found in different positions towards the kinetosome (Fig. 5A, B). Thus, we can assume that the centriole-like body in S. lacustris is a temporary structure associated with choanocyte division, later becoming the kinetosome of the new flagellum of the daughter choanocyte.

Figure 3. Series of transverse sections of the Spongilla lacustris flagellar apparatus. A-H, series of consecutive sections through the transition zone and kinetosome from distal to proximal end (view from inside the cell). I-L, selected sections from a series through the kinetosome from distal to proximal end of another choanocyte (view from outside the cell). M-P, selected sections from a series through the kinetosome from distal to proximal end of one more choanocyte (view from outside the cell). Q-T, single slightly oblique section through the kinetosome of different choanocytes at different levels. Abbreviations: as, axosome; cf, coil fiber; cmt, central microtubules; fr, fibrillar root; k, kinetosome; lmt, lateral microtubules; pdm, peripheral doublet of microtubules; ptm, peripheral triplet of microtubules; s, satellite; tf, transition fibre; usm, unstructured material. 

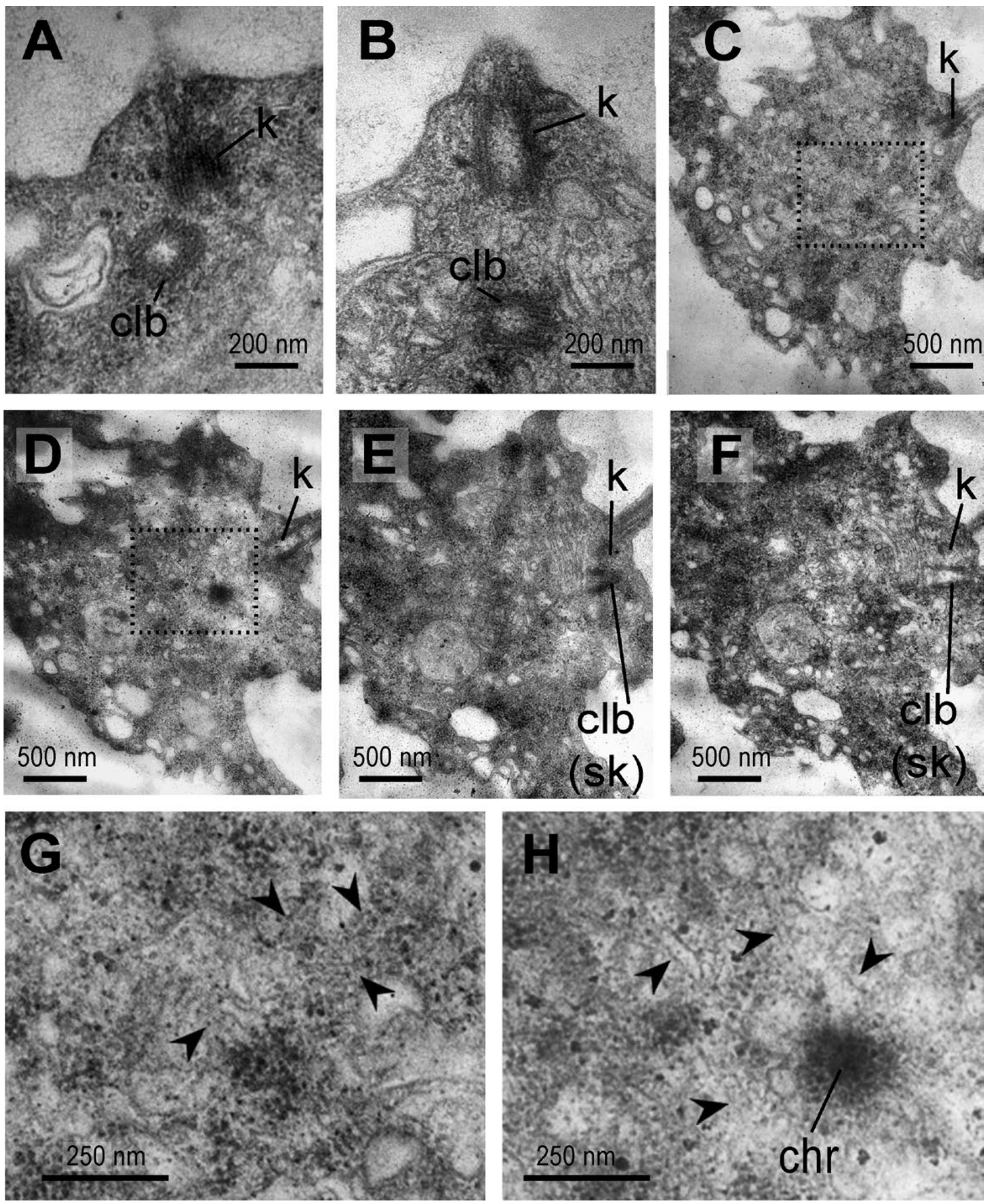

Figure 5. Centriole-like bodies in divided choanocytes of Spongilla lacustris. A, B, centriole-like body. C-F, choanocyte with resorbed nuclear envelope on a series of sections (from one side of the cell to the other side through the plane of the kinetosome). G, H, enlarged chromosomes with mitotic spindle microtubules from (C) and (D), respectively (dashed area). Abbreviations: chr, chromosome; clb, centriole-like body; k, kinetosome; sk, second kinetosome. Arrowheads, the spindle microtubules. 
An overall scheme of a choanocyte kinetid of S. lacustris is shown in Figure 6.

\section{KINETID STRUCTURE OF E. FLUVIATILIS}

In light of new data on the $S$. lacustris kinetid, we reexamined the TEM images of $E$. fluviatilis to highlight their differences and similarities. Several new details have to be added to the original investigation (Karpov \& Efremova, 1994).

1. As in S. lacustris, the flagellum of E. fluviatilis emerges from a small protrusion in the centre of the collar. However, it is less pronounced than in S. lacustris and the kinetosome does not fit entirely into it (Fig. 7A).

2. A thicker section in the middle of the transverse plate of $E$. fluviatilis can now be equated with the axosome of S. lacustris (Fig. 7B).

3. A coiled fibre in the transition zone above the transverse plate is present in both species.

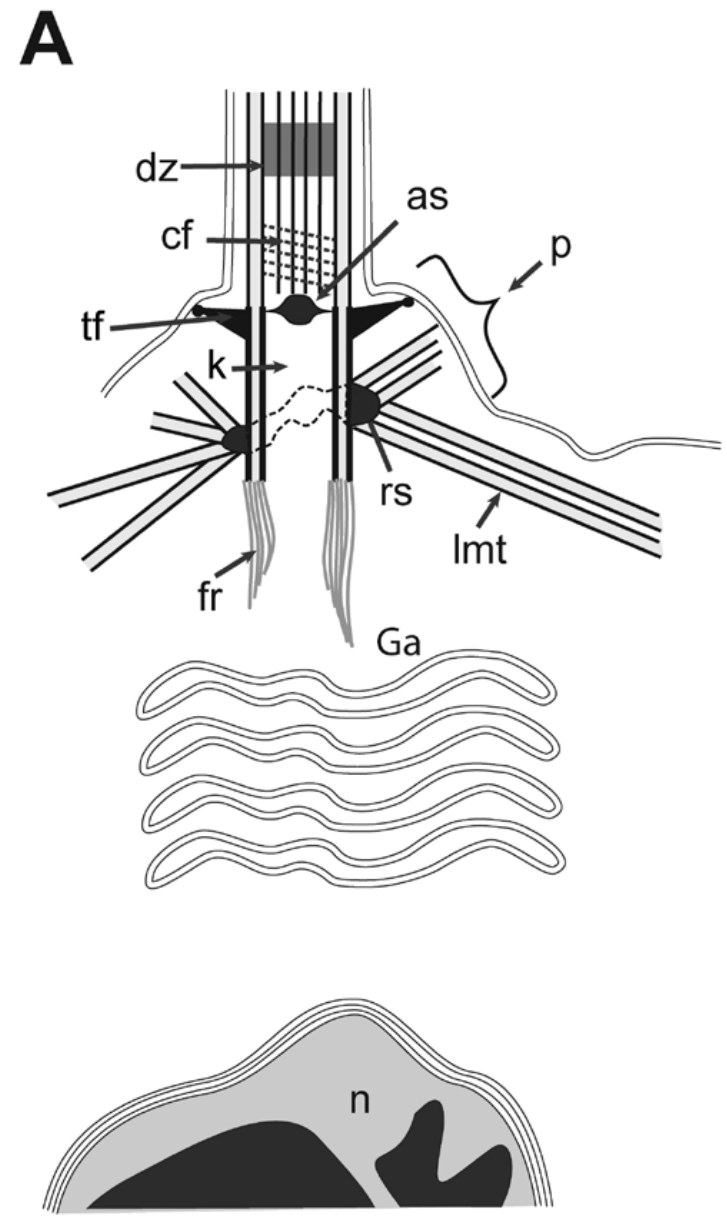

4. On the proximal end of the kinetosome, a few short, non-striated fibrillar roots similar to those in the kinetosome of $S$. lacustris are present (Fig. 7C-E).

5. A centriole-like structure, previously described as a centriole (Karpov \& Efremova, 1994), was observed with the same frequency as in S. lacustris choanocytes. Therefore, we consider it to be a provisional kinetosome that appears during cell division (Pozdnyakov \& Karpov, 2016).

Based on these observations, we conclude that the kinetid structure of $E$. fluviatilis choanocyte is substantially similar to that of S. lacustris and can be referred to as the same scheme (Fig. 6).

\section{KINETID STRUCTURE OF L. BAIKALENSIS}

Unlike S. lacustris, the choanocytes of L. baikalensis are elongated along the apical-basal axis (Fig. 8A). The general structure of the kinetid in L. baikalensis has many
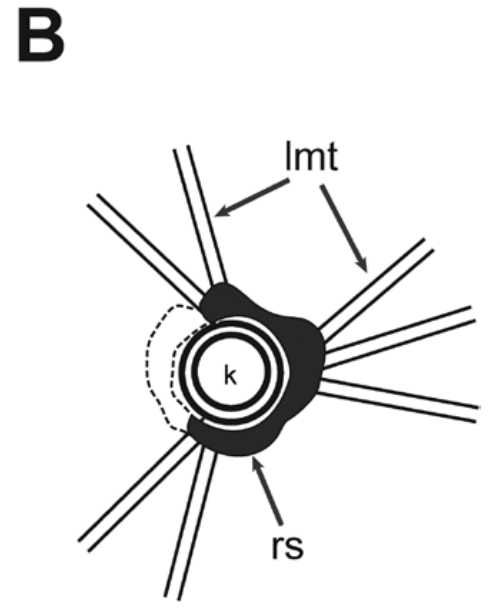

Figure 6. Reconstruction of a Spongilla lacustris kinetid. A, the lateral view. B, the kinetosome in plane. Abbreviations: as, axosome; cf, coil fibre; dz, dense zone; fr, fibrillar roots; Ga, Golgi apparatus; k, kinetosome; lmt, lateral microtubes; n, nucleus; $p$, protrusion at the base of flagellum; tf, transition fiber; rs, ring of satellites; usm, unstructured material. 

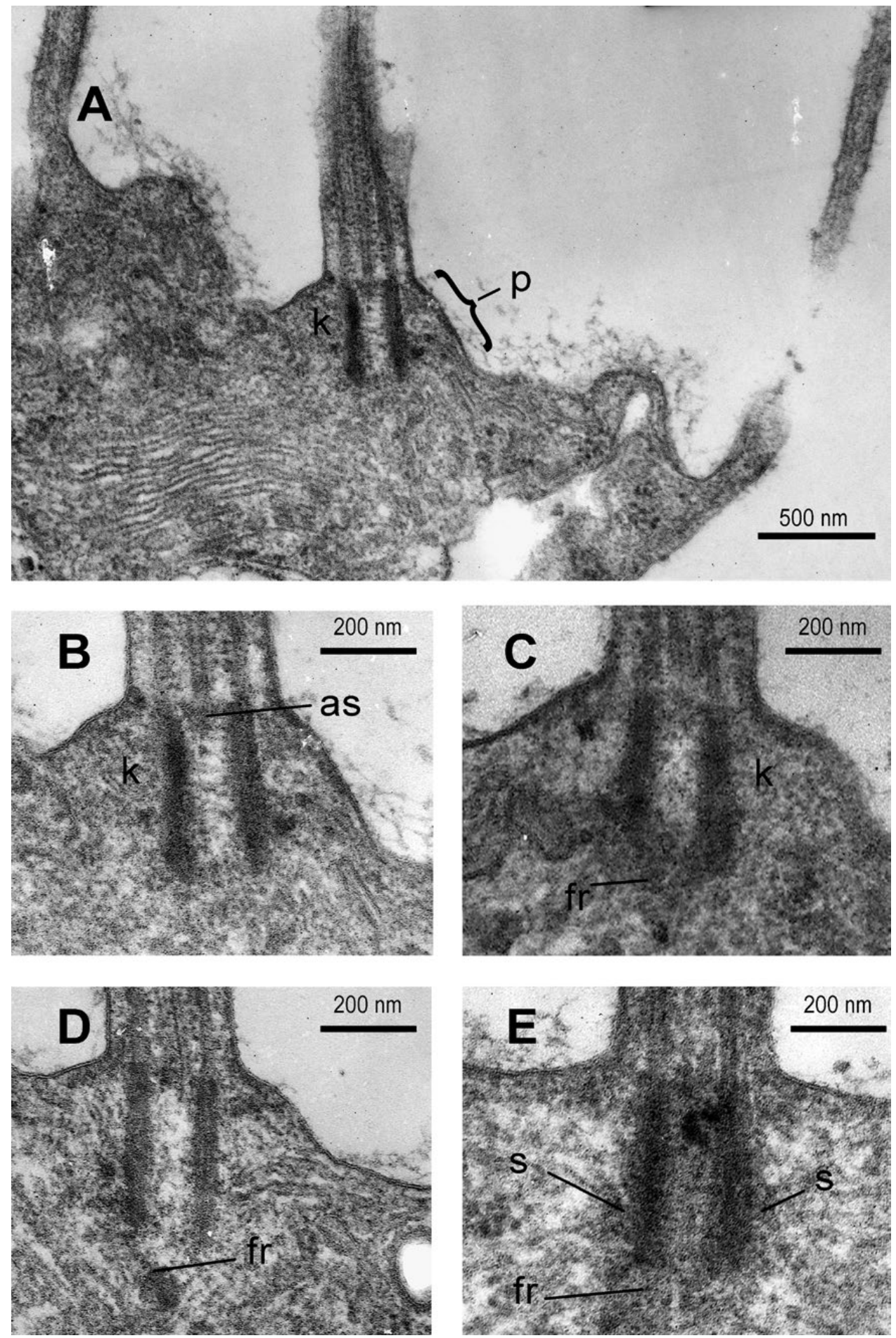

Figure 7. Some details of the kinetid structure of Ephydatia fluviatilis in different longitudinal sections. A, starting of flagellum; B, axosome with the ending of central microtubule; $\mathrm{C}-\mathrm{E}$, fibrillar roots; E, satellites location. Abbreviations: as, axosome; fr, fibrillar roots; $\mathrm{k}$, kinetosome; $\mathrm{p}$, protrusion at the base of flagellum; s, satellite.

similarities to that of S. lacustris (Fig. 8), including: a basal nucleus (Fig. 8A), a transverse plate with an axosome (Fig. 8B, D), satellites with microtubules located at the surface of the kinetosome (Fig. 8B-D), short fibrillar roots (Fig. 8D), and a Golgi apparatus underlying the kinetosome (Fig. 8B). The general disposition of 

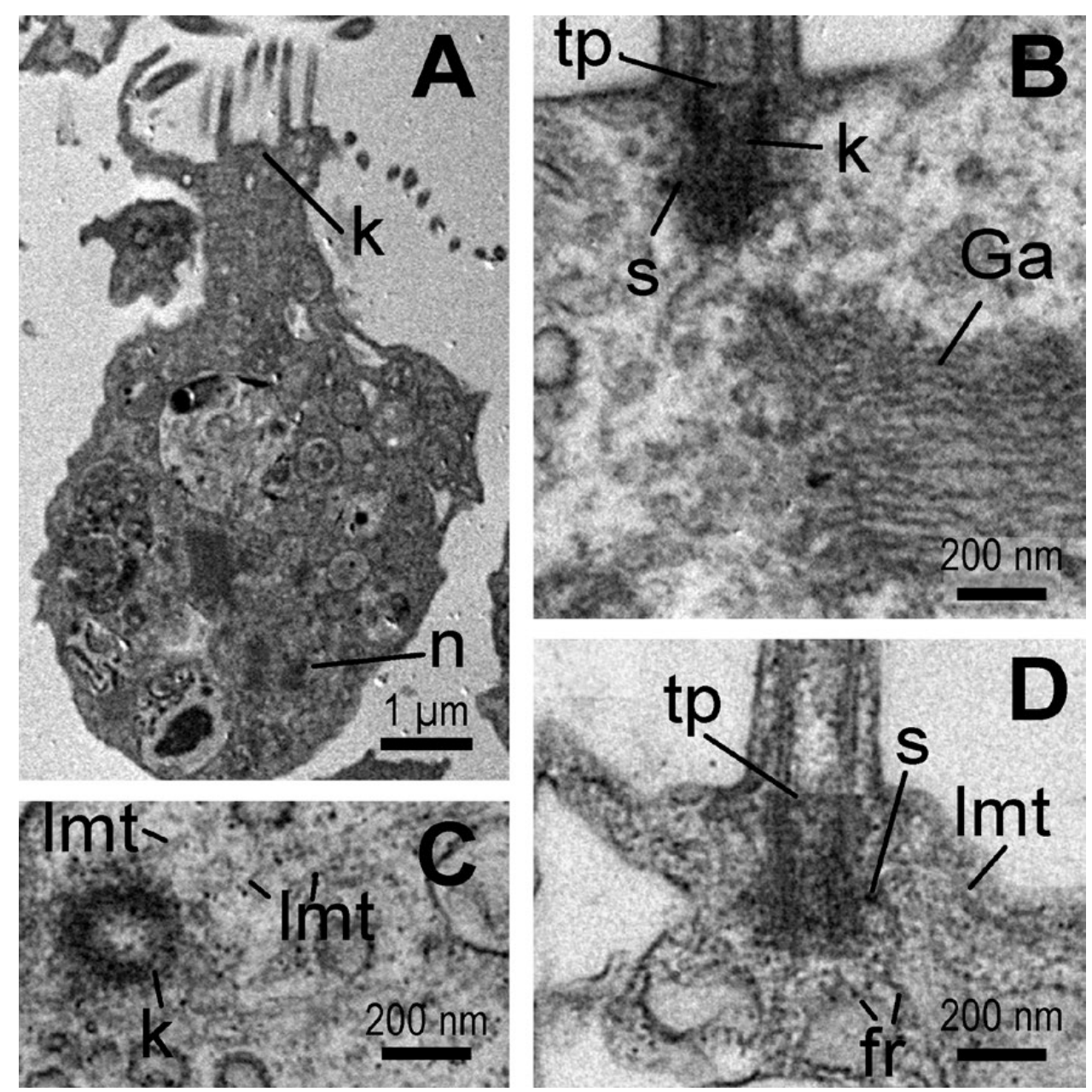

Figure 8. General view of a choanocyte of Lubomirskia baikalensis in a longitudinal section and some details of its kinetid structure. A, general view of a choanocyte. B, longitudinal section through the kinetosome and Golgi complex. C, transverse section through the kinetosome with lateral microtubules. D, longitudinal section through the middle of kinetosome. Abbreviations: fl, flagellum; Ga, Golgi apparatus; k, kinetosome; lmt, lateral microtubes; n, nucleus; s, satellite; tp, transition fiber.

the marked structures and organelles is similar to that of S. lacustris. Thus, in general, we may assume that the key kinetid characters of L. baikalensis choanocytes follow the scheme as proposed for S. lacustris (Fig. 6).

\section{DISCUSSION}

The kinetids of S. lacustris, E. fluviatilis and L. baikalensis proved to be notably similar; this was to be expected, since these sponges belong to the one monophyletic group inside the order Spongillida (Manconi \& Pronzato, 2002; Itskovich et al., 2008; Redmond et al., 2013; Morrow \& Cárdenas, 2015). The obtained data corresponds with the image of the kinetid in collar cells of Ephydatia muelleri (Lieberkuhn, 1855) presented by Garrone et al. (1980). It can be assumed that other members of this group also possess the same type of kinetid, yet, we do not have enough data to make a general conclusion about the choanocyte flagellar apparatus for the entire order.

In our previous works (Pozdnyakov \& Karpov, 2015, 2016), we found three types of demospongian kinetids. The Type I kinetid can be observed in sponges from the Verongimorpha + Keratosa branch, in the subclass Verongimorpha (Halisarca dujardini Gonobobleva \& Maldonado, 2009; Aplysina aerophoba - Maldonado, 2009) and in the subclass Keratosa (Lamellodysidea sp. - Pozdnyakov et al., unpublished). Its kinetosome is connected to the nucleus by the fibrillar roots, the centriole is located at a sharp angle to the kinetosome, two microtubule organizing centers (MTOCs) shaped like distinct bodies (large basal foot and smaller satellite), the long transition zone bears the axial granule at the top of the kinetosome (Fig. 9) (Pozdnyakov \& Karpov, 2016). 


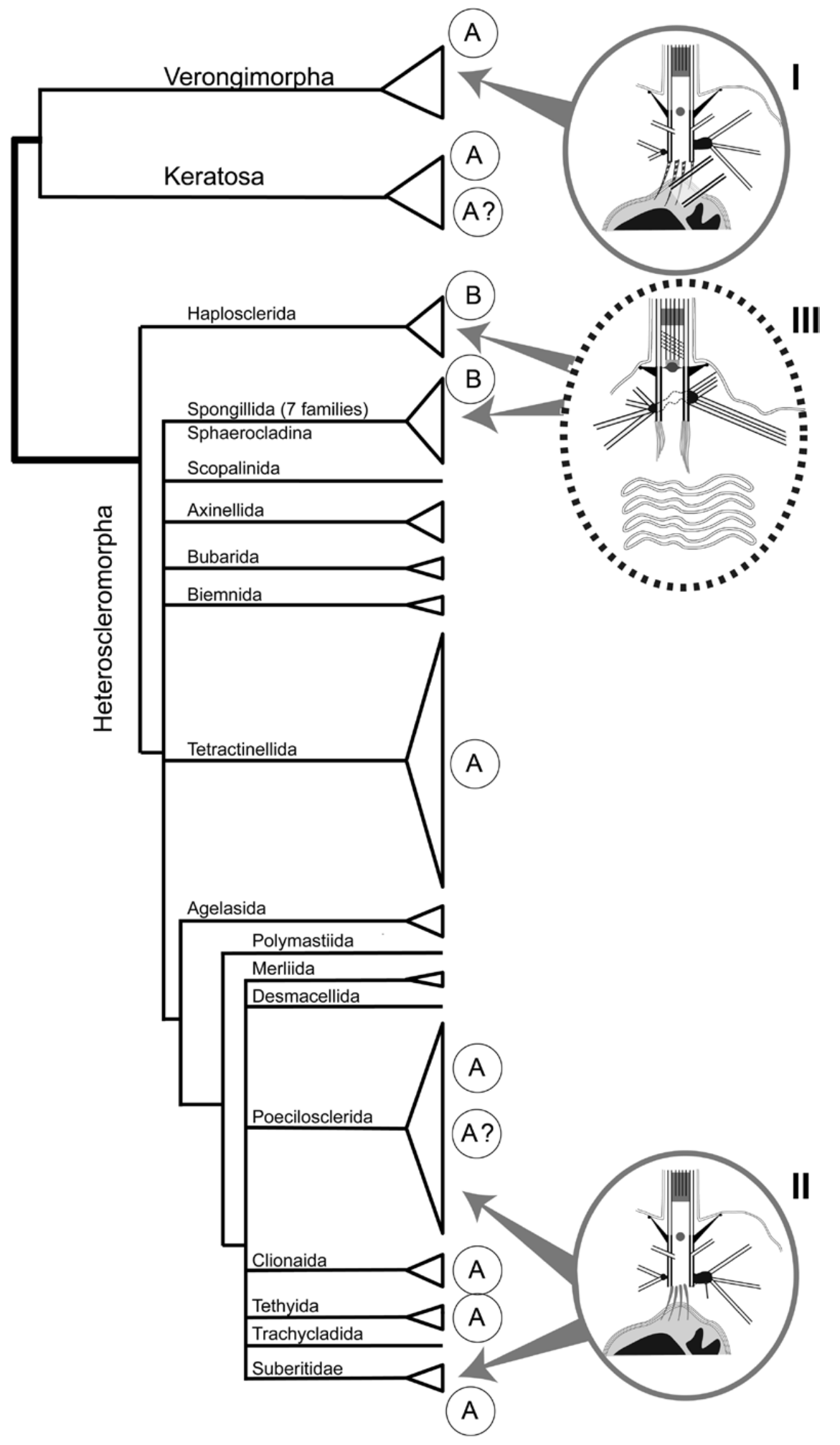

Figure 9. Three kinetid types on the phylogenetic tree of Demospongiae (from: Morrow \& Cárdenas, 2015, modified) and position of the nucleus in choanocytes of some orders (according to Table 2). Abbreviations: I, II, III, noted kinetid types. A, clear apical position of nucleus; A?, assumed apical position of nucleus; B, clear basal position of nucleus. 
The type II kinetid occurs in representatives of the orders Suberitida (Halichondria sp.) and Poecilosclerida (Crellomima imparidens) (Pozdnyakov \& Karpov, 2016). Its general characters coincide with those of type I, except for an absence of the centriole in type II (Fig. 9).

The type III kinetid was found in representatives of the orders Haplosclerida (Haliclona sp., Haliclona indistincta) and Spongillida (E. fluviatilis). It has no kinetosome-nucleus connection and no centriole, the MTOCs are shaped like few satellites of different sizes encircling the kinetosome, short transition zone with coil fibre and the axial granule (Fig. 9).

The new descriptions of kinetid structure in Spongillida presented here agree with earlier data concerning the choanocyte kinetid of sponges from this order. However, it is necessary to make some adjustments to the scheme of type III kinetids published earlier (Pozdnyakov \& Karpov, 2016).

Comparing the newly observed Spongillida and Haliclona (Pozdnyakov \& Karpov, 2015) reveals an additional common element in their kinetid structure: the presence of short fibrillar roots. Short roots were also described in E. fluviatilis by Brill (1973). Therefore, the non-striated fibrillar roots can be considered as a permanent character of the type III kinetid.

Previously we distinguished type III as having several small satellites associated with the kinetosome instead of one the large basal foot and one small satellite as in types I and II. But, the satellites in S. lacustris comprise the ring around the kinetosome; they are of variable size, comparable in some cases with the basal feet of types I and II. Since the relative size of MTOCs is variable, they cannot be a distinguishing feature of the kinetid. In the type III kinetid, the MTOCs are dispersed around the kinetosome and even encircling it, while in the two other kinetid types the MTOCs are concentrated in a single basal foot and a satellite (Pozdnyakov \& Karpov, 2013, 2015). Thus, the organization of the MTOC becomes a discriminatory character of choanocyte kinetids.

The position of the axosome in the transverse plate of Spongillida is similar to the position of the axial granule of sponges without a transverse plate (Pozdnyakov $\&$ Karpov, 2016). These two structures might be homologous in sponges. Possibly, more detailed study will reveal axosomes in Haliclona or other sponge species with a transverse plate and then the axosome will be recognized as the common character of kinetid type III.

The issue of presence/absence of the centriole in choanocytes of Spongillida is now clarified: the centriolelike bodies in Spongillida are temporary attributes of the cell division process. The centriole is absent in the interphase choanocytes of S. lacustris and other studied Spongillida, and in the choanocytes of other studied Heteroscleromorpha. As such, the absence of a centriole remains a common character of kinetid types II and III. Reconsidered features of the three kinetid structures are listed in Table 1.

We found three kinetid types in the class Demospongiae. They are described for 11 species belonging to seven orders. It is not enough to describe the kinetid type as a characteristic of the order, or for a detailed reconstruction of this structure's evolutionary changes. However, these data can provide the basis for revealing the ancestral variants of the kinetid and allow us to note the points on phylogenetic tree where the kinetid has transformed.

By finding similar kinetid structures in representatives of related orders, one can consider the kinetid inherited from common ancestor. Furthermore, if a species of any order with a kinetid structure different from the supposed ancestral form is found, it would reveal the morphological transformation that took place in the lineage of this order (regardless of whether this happened in common ancestor of the order or inside the lineage of this species particularly).

Therefore, even small number of studied kinetid structures can be used to reconstruct the basic elements of the ancestral kinetid and to draft a scheme of morphological transformations in different branches of Porifera.

This scheme, even in the present form, allows us to have some expectation of the structure of the choanocyte kinetid of an unstudied species and remains open to additional data and further analysis.

Additional information about the kinetid types' distribution in the demospongian phylogenetic tree can be obtained from the nuclear location in the choanocytes, as discussed below.

\section{NUCLEUS POSITION IN THE CHOANOCYTE AND KINETID STRUCTURE}

As we noticed in previous works (Pozdnyakov \& Karpov, 2016), in described kinetid types the nucleus location in the choanocyte correlates with some features of the kinetid structure: besides the obvious kinetosomenuclear connection and fibrillar root development, the structure of the MTOCs and the transition flagellar zone also correlate with the basal or apical location of the nucleus (Karpov \& Efremova, 1994; Gonobobleva \& Maldonado, 2009; Pozdnyakov \& Karpov, 2013, 2015, 2016). Therefore, the nuclear position in choanocytes could inform the kinetid structure types.

According to the literature, in Demospongiae, the nucleus may be located in both the basal and apical parts of choanocytes. It is also necessary to specify the situation when the nuclear apical-basal extension, including the nuclear 'beak', is comparable with 


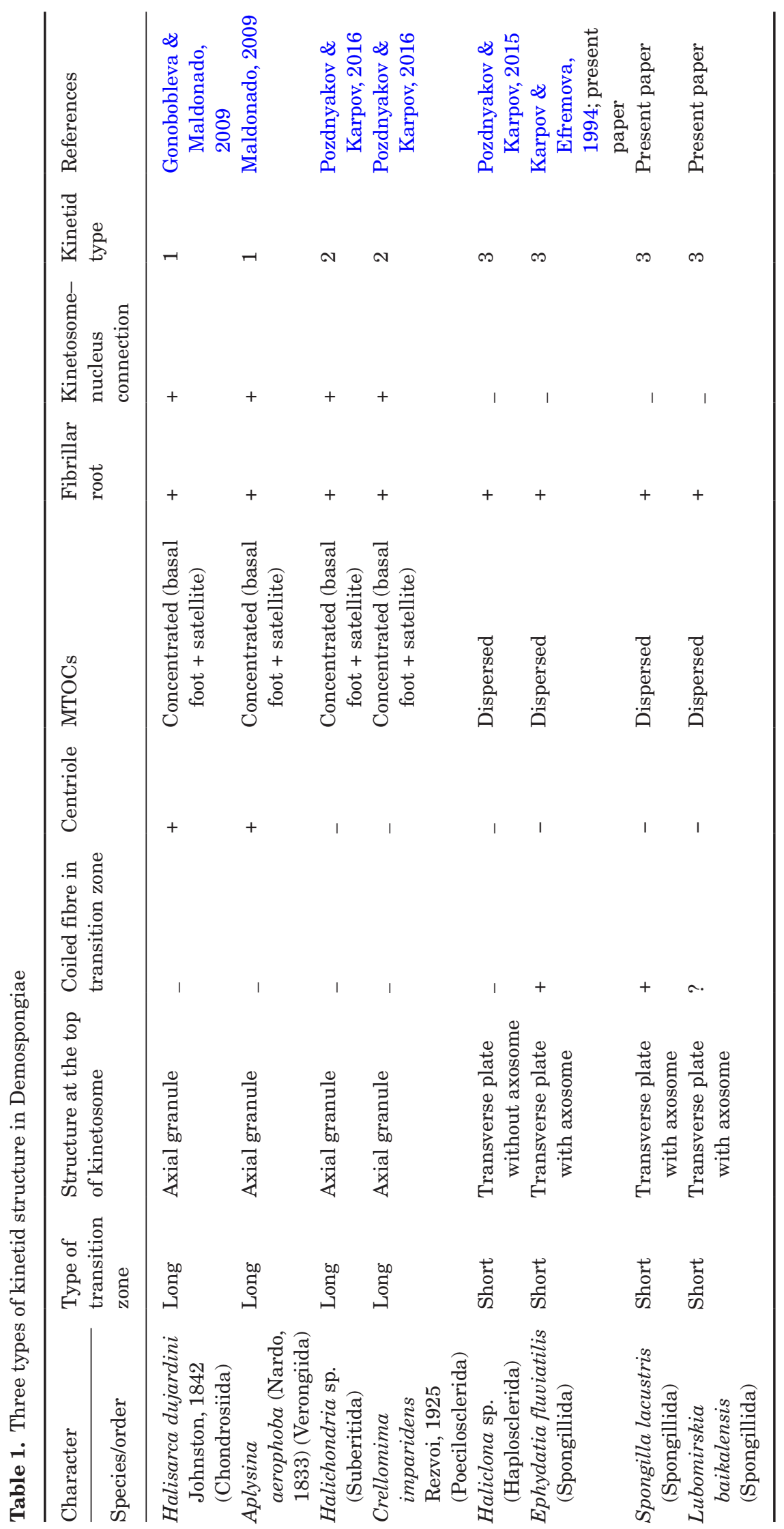

(C) 2018 The Linnean Society of London, Zoological Journal of the Linnean Society, 2018, XX, 1-18 
the size of the choanocyte. This is usually observed in flattened choanocytes, but is possible in the elongated choanocyte as well. In the case when the dimensions of the nucleus and the choanocyte are comparable, the nucleus can be connected to the kinetosome through the fibrillar roots at the apical pole and can reach the cell membrane at the basal pole. Herewith the nucleus may turn out to be closer to the cell membrane on the basal pole, since the place occupied by the kinetosome remains on the apical end. In such a position, the nucleus cannot be called basal, since, by joining spatially to the basal pole of the cell, the nucleus is structurally related to the apical pole.

We described such position in Halichondria sp., where the choanocyte is flattened along the apicalbasal axis (Pozdnyakov \& Karpov, 2016). The same situation is observed in Crambe crambe (see fig. 17 in Turon, Galera \& Uriz, 1997). The apical-basal length of the choanocyte is comparable to the size of the nucleus and the nucleus, associated with the kinetosome, is located near the membrane on the basal pole of the cell. The section of the C. crambe choanocyte in a non apical-basal plane (fig. 2 in Riesgo \& Maldonado, 2009) would likely not reflect the real position of the nucleus relative to the kinetosome.

To confirm the basal position of the nucleus, we have to show that nuclear apical-basal dimension including a 'beak' is substantially less than the corresponding size of the choanocyte, or that the Golgi apparatus is located between the nucleus and the kinetosome.

Therefore, we analyzed published and unpublished images of longitudinal sections of the choanocytes (Table 2). Almost all representatives of Verongimorpha + Keratosa with one exception (Gaino et al., 1984) have an apical nucleus. As such, these species have the kinetosome-nucleus connection, and we can expect the type I kinetid in this branch, as it was shown already for some species (Pozdnyakov \& Karpov, 2016). The exception, a dyctioceratid species Spongia officinalis Linnaeus, 1759, was investigated during spermatogenesis (Gaino et al., 1984) and the choanocyte located in mesohyl (out of a choanocyte chamber) was not regular but had undergone a process of transformation. The kinetid of the normal choanocyte has to be studied to clarify this exception.

Most choanocytes of Heteroscleromorpha, besides the orders Haplosclerida and Spongillida, have an apical nucleus, based on the published images.

Scrutiny of available information reveals an unambiguous basal position of the nucleus in Haplosclerida and Spongillida only. The basal position of the nucleus in the order Haplosclerida was registered in the various, even distantly related species (Redmond et al., 2011). As such, we propose that all haplosclerids have a kinetid structure similar to that observed in
Haliclona sp. (Pozdnyakov \& Karpov, 2016). Therefore, we can predict that the majority of haplosclerids have a type III kinetid. For freshwater sponges, data from the literature (Table 2) agree with our data in that E. fluviatilis and L. baikalensis have a type III kinetid.

\section{ON THE TRENDS OF KINETID TRANSFORMATION IN EVOLUTION OF DEMOSPONGIAE}

The issue of the phylogenetic relationships between the three kinetid types remains unresolved at present, though the data collected allow us to produce the initial scheme of evolutionary kinetid transformations. Kinetid type II (found in C. imparidens and Halichondria sp.) or a similar type could be proposed for several other species of Poecilosclerida and Suberitida and for species of Tethyida, Clionaida and Tetractinellida on the basis of nuclear position (Table 2). This leads us to suggest that this kinetid type could be the feature of the common ancestor of a cluster including all of these orders.

Type I kinetid presence in all studied representatives of the branch Verongimorpha + Keratoza suggests that this type is the ancestral kinetid for this group. The type II kinetid is nearly identical to type I devoid of a centriole, which was probably lost though evolution. Thus, the type I kinetid appears to be ancestral for one of the main branches of Demospongiae and its close derivative can be found in species of other branch. Our working hypothesis for future studies is that the type I kinetid most closely resembles the kinetid of a common ancestor of Demospongiae.

The kinetids of Spongillida and Haplosclerida (type III) appear to have undergone further modifications from the ancestral state. The absence of the centriole associates this type with type II. However, several changes are required to evolve from type II to type III. The transition zone has to become restructured and shortened, the connection between the kinetosome and nucleus has to be lost and the concentrated MTOC has to become dispersed.

In the morphological system, freshwater sponges were included in the order Haplosclerida (Hooper \& van Soest, 2002) as a family Spongillidae. Since 2004, a bulk of studies (Borchiellini et al., 2004; Morrow et al., 2012; Wörheide et al., 2012; Morrow \& Cárdenas, 2015) distinctly separated Haplosclerida from Spongillida. This change was also confirmed by the recent multigene analysis conducted by Simion et al. (2017). However, molecular surveys claiming a close relationship between these groups periodically appear (Sperling et al., 2009; Hill et al., 2013; Schuster et al., 2017). Their relationship was also supported by morphological similarities in the skeletal morphotraits, an ability to produce resistant bodies (Manconi \& Pronzato, 2002, 
Table 2. Position of the nucleus in the choanocytes of Demospongiae

\begin{tabular}{|c|c|c|c|}
\hline Taxa & Apical & Basal & References \\
\hline \multicolumn{4}{|l|}{ Chondrillida } \\
\hline Chondrilla nucula & Clearly & & Ereskovsky, unpublished \\
\hline Chondrilla sp. & Clearly & & Ereskovsky, unpublished \\
\hline Halisarca cearulea & Clearly & & Ereskovsky, unpublished \\
\hline Halisarca harmelini & Clearly & & Ereskovsky et al., 2011 \\
\hline Halisarca magellanica & Clearly & & Willenz, Ereskovsky \& Lavrov, 2017 \\
\hline Thymosiopsis conglomerans & Clearly & & Vacelet et al., 2000 \\
\hline \multicolumn{4}{|l|}{ Chondrosiida } \\
\hline Chondrosia reniformis & Clearly & & Ereskovsky, unpublished \\
\hline \multicolumn{4}{|l|}{ Dictyoceratida } \\
\hline Scalarispongia scalaris & Clearly & & Vacelet et al., 1989 \\
\hline Pleraplysilla spinifera & Clearly & & Donadey \& Vacelet, 1977 \\
\hline Dysidea avara & Clearly & & Turon et al., 1997 \\
\hline Spongia officinalis & $\begin{array}{l}\text { Possibly (probably changed by } \\
\text { spermatogenesis) }\end{array}$ & & Ref. 'Discussion' of present paper \\
\hline \multicolumn{4}{|l|}{ Dendroceratida } \\
\hline Chelonaplysilla noevus & Clearly & & Vacelet et al., 1989 \\
\hline \multicolumn{4}{|l|}{ Verongida } \\
\hline Hexadella pruvoti & Clearly & & Reveillaud et al., 2012 \\
\hline Hexadella crypta & Clearly & & Reveillaud et al., 2012 \\
\hline Hexadella racovitzai & Clearly & & Reveillaud et al., 2012 \\
\hline Hexadella topsenti & Clearly & & Reveillaud et al., 2012 \\
\hline \multicolumn{4}{|l|}{ Suberitida } \\
\hline Suberites domuncula & Clearly & & Ereskovsky, unpublished \\
\hline \multicolumn{4}{|l|}{ Clionaida } \\
\hline Willardia caicosensis & Possibly (probably apical elongated) & & Willenz \& Pomponi, 1996 \\
\hline \multicolumn{4}{|l|}{ Haplosclerida } \\
\hline Haliclona cinerea & & Clearly & Ereskovsky, unpublished \\
\hline Haliclona fulva & & Clearly & Ereskovsky, unpublished \\
\hline Haliclona mucosa & & Clearly & Ereskovsky, unpublished \\
\hline Haliclona permollis & & Clearly & Amano \& Hori, 1996 \\
\hline Pellina fistulosa & & Clearly & Langenbruch \& Jones, 1989 \\
\hline Pellina semitubulosa & & & Sciscioli et al., 1997 \\
\hline Callyspongia diffusa & & Clearly & Smith \& Hildemann, 1990 \\
\hline Amphimedon queenslandica & & Clearly & Sogabe, Nakanishi \& Degnan, 2016 \\
\hline \multicolumn{4}{|l|}{ Suberitida } \\
\hline Hymeniacidon perlevis & Clearly & & Maldonado et al., 2010 \\
\hline \multicolumn{4}{|l|}{ Poecilosclerida } \\
\hline Hemimycale columella & Possibly (probably apical elongated) & & Willenz, unpublished \\
\hline Hymedesmia irregularis & Possibly (probably apical elongated) & & Ereskovsky, unpublished \\
\hline Iophon proximum & Possibly (probably apical elongated) & & Willenz, unpublished \\
\hline Phorbas topsenti & Possibly (probably apical elongated) & & Vacelet \& Perez, 2008 \\
\hline Mycale microstigmatosa & Possibly (probably apical elongated) & & Alexander, 2015 \\
\hline Crambe crambe & Clearly & & Turon et al., 1997 \\
\hline \multicolumn{4}{|l|}{ Tetractinellida } \\
\hline Craniella serica & Clearly & & Watanabe, 1978 \\
\hline \multicolumn{4}{|l|}{ Tethyida } \\
\hline Tethya seychellensis & Clearly & & Gaino et al., 2009 \\
\hline Tethya sp. & Clearly & & Pozdnyakov, unpublished \\
\hline \multicolumn{4}{|l|}{ Spongillida } \\
\hline Ephydatia muelleri & $\begin{array}{l}\text { Possibly (on the grounds of Golgi } \\
\text { apparatus position) }\end{array}$ & & Garrone et al., 1980 \\
\hline Lubomirskia baikalensis & & Clearly & Ereskovsky, Chernogor \& Belikov, 2016 \\
\hline Ephydatia fluviatilis & & Clearly & Funayama et al., 2010 \\
\hline
\end{tabular}


2007), some embryological characters (Ereskovsky, 2010) and the features of the kinetid structure in their choanocytes (Pozdnyakov \& Karpov, 2015).

Confirmation of molecular kinship would explain all the marked coincidences in the morphology of Haplosclerida and Spongillida. However, at present, molecular-phylogenetic studies presenting Spongillida and Haplosclerida as non-related groups prevail; these orders are considered separated from the common Heteroscleromorpha trunk independently from each other. In this case, some morphological similarities between sponges of these two orders can be symplesiomorphic. However, according to our hypothesis, the choanocyte kinetid of Spongillida and Haplosclerida is advanced compared to that of their ancestor, and the similarity of the kinetid structure in these orders can only be explained by evolutionary parallelism.

Perhaps the structure of the kinetid will prove to be a character that can help clarify the positioning of these two orders. To achieve clarity, and for a general understanding of the ways in which this character has evolved within Demospongiae, an investigation of the kinetid structure in unstudied representatives of Heteroscleromorpha (especially of orders Axinellida, Scopalinida, Biemnida, Bubarida, Desmacellida) is needed.

\section{ACKNOWLEDGEMENTS}

The research was supported by the Russian Foundation for Basic Research (projects no. 16-34-50010 and 15-0403324) and by the Program of the Presidium of Russian Academy of Sciences 'Evolution of the biosphere' (SAK). The authors thank the Research Resource Center for Molecular and Cell Technologies (RRC MCT) at St. Petersburg State University (SPbSU) for access to the EM facilities. The authors thank Joël Courageot and Alexandre Altié of Service Commun de Microscopie Électronique et Photographie Faculté de Médecine La Timone, Aix-Marseille Université. We also personally thank N. Yu. Vetrov for ensuring the quality and smooth operation of the machinery, I. A. Udalov and V. V. Zlatogursky for participating in the discussion of ideas and the results of our study, the coworking space, Lab. 1.62, for a creative atmosphere for intellectual work, and Yu. Tamberg and B. S. C. Leadbeater for the English correction. A particular thanks to Sandrine Chenesseau from the morphology staff of the Mediterranean Institute of Marine and Terrestrial Biodiversity and Ecology (IMBE) laboratory.

\section{REFERENCES}

Alexander BE. 2015. Cell turnover in marine sponges: insight into poriferan physiology and nutrient cycling in benthic ecosystems. PhD Thesis. University of Amsterdam. UvA-DARE
(Digital Academic Repository). Available at: http://hdl. handle.net/11245/1.495338

Amano S, Hori I. 1996. Transdifferentiation of larval flagellated cells to choanocytes in the metamorphosis of the demosponge Haliclona permollis. Biological Bulletin 190: 161-172.

Bergquist PR. 1978. Sponges. Berkeley: University of California Press.

Borchiellini C, Chombard C, Manuel M, Alivon E, Vacelet J, Boury-Esnault N. 2004. Molecular phylogeny of Demospongiae: implications for classification and scenarios of character evolution. Molecular Phylogenetics and Evolution 32: 823-837.

Brill B. 1973. Untersuchungen zur ultrastruktur der choanocyte von Ephydatia fluviatilis L. Zeitschrift Fur Zellforschung Und Mikroskopische Anatomie 144: 231-245.

Donadey C, Vacelet J. 1977. Les cellules à inclusions de l'éponge Pleraplysilla spinifera (Schulze) (Démosponges, Dendroceratides). Archives de Zoologie Expérimentale et Générale 118: 273-284.

Ereskovsky AV. 2010. The comparative embryology of sponges. Amsterdam: Springer, Science \& Business Media.

Ereskovsky AV, Chernogor LI, Belikov SI. 2016. Ultrastructural description of development and cell composition of primmorphs in the endemic Baikal sponge Lubomirskia baicalensis. Zoomorph 135: 11-17.

Ereskovsky AV, Lavrov DV, Boury-Esnault N, Vacelet J. 2011. Molecular and morphological description of a new species of Halisarca (Demospongiae: Halisarcida) from Mediterranean Sea and a redescription of the type species Halisarca dujardini. Zootaxa 2768: 5-31.

Funayama N, Nakatsukasa M, Mohri K, Masuda Y, Agataa K. 2010. Piwi expression in archeocytes and choanocytes in demosponges: insights into the stem cell system in demosponges. Evolution \& Development 12: 275-287.

Gaino E, Burlando B, Zunino L, Pansini M, Buffa P. 1984. Origin of male gametes from choanocytes in Spongia officinalis (Porifera, Demospongiae). Invertebrate Reproduction and Development 7: 83-93.

Gaino E, Mercurio M, Sciscioli M, Corriero G. 2009. Choanocyte chambers in unreleased buds of Tethya seychellensis (Wright, 1881) (Porifera, Demospongiae). Italian Journal of Zoology 76: 64-69.

Garrone R, Lethias C, Escaig J. 1980. Freeze fracture study of sponge cell-membranes and extracellular matrix. Preliminary results. Biologie Cellulaire 38: 71-74.

Gazave E, Lapébie P, Ereskovsky AV, Vacelet J, Renard E, Cárdenas P, Borchiellini C. 2012. No longer Demospongiae: Homoscleromorph sponges revisited by molecular phylogeny, Linnaean classification and the PhyloCode. Hydrobiologia 687: $3-10$.

Gonobobleva E, Maldonado M. 2009. Choanocyte ultrastructure in Halisarca dujardini (Demospongiae, Halisarcida). Journal of Morphology 270: 615-627.

Hill MS, Hill AL, Lopez J, Peterson KJ, Pomponi S, Diaz MC, Thacker RW, Adamska M, Boury-Esnault N, Cárdenas P, Chaves-Fonnegra A, Danka E, De Laine BO, Formica D, Hajdu E, Lobo-Hajdu G, Klontz S, Morrow CC, Patel J, Picton B, Pisani D, Pohlmann 
D, Redmond NE, Reed J, Richey S, Riesgo A, Rubin E, Russell Z, Rützler K, Sperling EA, di Stefano M, Tarver JE, Collins AG. 2013. Reconstruction of familylevel phylogenetic relationships within Demospongiae (Porifera) using nuclear encoded housekeeping genes. PLoS ONE 8: e50437.

Hooper JNA, van Soest RWM (eds). 2002. Systema Porifera: a guide to the classification of sponges. New York: Kluwer Academic / Plenum Publishers.

Itskovich V, Gontcharov A, Masuda Yo, Nohno T, Belikov S, Efremova S, Meixner M., Janussen D. 2008. Ribosomal ITS sequences allow resolution of freshwater sponge phylogeny with alignments guided by secondary structure prediction. J Mol Evol 67: 608-620.

Karpov SA, Efremova SM. 1994. Ultrathin structure of the flagellar apparatus in the choanocyte of the sponge Ephydatia fluviatilis. Tsitologia 36: 403-408 (in Russian).

Langenbruch P.-F, Jones WC. 1989. A new type of central cell in the choanocyte chambers of Pellina fistulosa (Porifera, Demospongiae). Zoomorph 109: 1-14

Lévi C. 1953. Sur une nouvelle classification des Démosponges. $C R$ hebd séan Acad sci. Paris 236: 853-855.

Maldonado M. 2009. Embryonic development of verongid demosponges supports the independent acquisition of spongin skeletons as an alternative to the siliceous skeleton of sponges. Biol J Linn Soc 97: 427-447.

Maldonado M, Zhang X, Cao X, Xue L, Cao H, Zhang W. 2010. Selective feeding by sponges on pathogenic microbes: a reassessment of potential for abatement of microbial pollution. Mar Ecol Prog Ser 403: 75-89.

Manconi R, Pronzato R. 2002. Suborder Spongillina subord. nov.: Freshwater sponges. In: Hooper JNA, van Soest RWM, eds. Systema Porifera: a guide to the classification of sponges, Vol. 1. New York: Kluwer Academic/Plenum Publishers, 921-1019.

Manconi R, Pronzato R. 2007. Gemmules as a key structure for the adaptive radiation of freshwater sponges: a morphofunctional and biogeographical study. In: Custódio MR, Lôbo-Hajdu G, Hajdu E, Muricy G, eds. Porifera research: biodiversity, innovation and sustainability. Série Livros 28. Rio de Janeiro: Museu Nacional, 233-237.

Manconi R, Pronzato R. 2015. Phylum Porifera. In: Thorp J, Rogers DC, eds. Ecology and general biology: Thorp and Covich's freshwater invertebrates, 4th edn, Vol. 1. London: Academic Press, 133-157.

Morrow CC, Cárdenas P. 2015. Proposal for a revised classification of the Demospongiae (Porifera). Frontiers in Zoology 12:7.

Morrow CC, Picton BE, Erpenbeck D, Boury-Esnault N, Maggs CA, Allcock AL. 2012. Congruence between nuclear and mitochondrial genes in Demospongiae: a new hypothesis for relationships within the G4 clade (Porifera: Demospongiae). Molecular Phylogenetics and Evolution 62: 174-190.

Morrow CC, Redmond NE, Picton BE, Thacker RW, Collins AG, Maggs CA, Sigwart JD, Allcock AL. 2013. Molecular phylogenies support homoplasy of multiple morphological characters used in the taxonomy of
Heteroscleromorpha (Porifera: Demospongiae). Integrative and Comparative Biology 53: 428-446.

Pozdnyakov IR, Karpov SA. 2013. Flagellar apparatus structure of choanocyte in Sycon sp. and its significance for phylogeny of Porifera. Zoomorph 132: 351-357.

Pozdnyakov IR, Karpov SA. 2015. Structure of choanocyte's kinetid in sponge Haliclona sp. (Demospongiae, Haplosclerida) and its implication for taxonomy and phylogeny of Demospongiae. Journal of Zoology 94: 17-25 (in Russian).

Pozdnyakov IR, Karpov SA. 2016. Kinetid structure in choanocytes of sponges (Heteroscleromorpha): toward the ancestral kinetid of Demospongiae. Journal of Morphology 277: 925-934.

Redmond NE, Morrow CC, Thacker RW, Diaz MC, BouryEsnault N, Cárdenas P, Hajdu E, Lôbo-Hajdu G, Picton BE, Pomponi SA, Kayal E, Collins AG. 2013. Phylogeny and systematics of Demospongiae in light of new small subunit ribosomal DNA (18S) sequences. Integrative and Comparative Biology 53: 388-415.

Redmond NE, Raleigh J, van Soest RWM, Kelly M, Travers SAA, Bradshaw B, Vartia S, Stephens KM, McCormack GP. 2011. Phylogenetic relationships of the marine Haplosclerida (phylum Porifera) employing ribosomal (28S rRNA) and mitochondrial (cox1, nad1) gene sequence data. PLoS ONE 6: e24344.

Reveillaud J, Allewaert C, Pérez T, Vacelet J, Banaigs B, Vanreusel A. 2012. Relevance of an integrative approach for taxonomic revision in sponge taxa: case study of the shallowwater Atlanto-Mediterranean Hexadella species (Porifera: Ianthellidae: Verongida). Invertebrate Systematics 26: 230-248.

Riesgo A, Maldonado M. 2009. An unexpectedly sophisticated, V-shaped spermatozoon in Demospongiae (Porifera): reproductive and evolutionary implications. Biological Journal of the Linnean Society 97: 413-426.

Sciscioli M, Lepore E, Corriero G, Scalera-Liaci L, Gaino E. 1997. Ultrastructural organization of choanocyte chambers in the haplosclerids Pellina semitubulosa (Porifera, Demospongiae): a cue for water flow into the sponge body. Italian Journal of Zoology 64: 291-296.

Schuster A, Vargas S, Knapp IS, Pomponi SA, Toonen RJ, Erpenbeck D, Wörheide G. 2017. Divergence times in demosponges (Porifera): first insights from new mitogenomes and the inclusion of fossils in a birth-death clock model. bioRxiv preprint. DOI: 10.1101/159806

Simion P, Philippe H, Baurain D, Jager M, Richter DJ, Franco AD, Roure B, Satoh N, Queinnec É, Ereskovsky A, Lapebie P, Corre E, Delsuc F, King N, Wörheide G, Manuel M. 2017. A large and consistent phylogenomic dataset supports sponges as the sister group to all other animals. Current Biology 27: 1-10.

Smith LC, Hildemann WH. 1990. Cellular morphology of Callyspongia diffusa (Porifera: Demospongia). In: Ruetzler K, Hartman W, eds. New perspectives in sponge biology. Washington: Smithsonian Institution Press, 135-143.

Sogabe S, Nakanishi N, Degnan BM. 2016. The ontogeny of choanocyte chambers during metamorphosis in the demosponge Amphimedon queenslandica. EvoDevo 7: 6. doi:10.1186/s13227-016-0042-x 
Sperling EA, Peterson KJ, Pisani D. 2009. Phylogeneticsignal dissection of nuclear housekeeping genes supports the paraphyly of sponges and the monophyly of Eumetazoa. Molecular Biology and Evolution 26: 2261-2274.

Turon X, Galera J, Uriz MJ. 1997. Clearance rates and aquiferous systems in two sponges with contrasting life-history strategies. Journal of Experimental Zoology 278: 22-36.

Watanabe Y. 1978. Structure and formation of the collar in choanocytes of Tetilla serica (Lebwohl), demosponge. Develop ment, Growth \& Differentiation 20: 79-91.

Vacelet J, Borchiellini C, Perez T, Bultel-Poncé V, Brouard JP, Guyot M. 2000. Morphological, chemical and biochemical characterization of a new species of sponge without skeleton (Porifera, Demospongiae) from the Mediterranean Sea. Zoosystema 22: 313-326.

Vacelet J, Boury·Esnault N, de Vos L, Donadey C. 1989. Comparative study of the choanosome of Porifera: 2. the keratose sponges. Journal of Morphology 201: 119-129.
Vacelet J, Perez T. 2008. Phorbas topsenti and Phorbas tailliezi (Demospongiae, Poecilosclerida), new names for the Mediterranean Phorbas paupertas and Phorbas coriaceus. Zootaxa 1873: 26-38.

Willenz P, Ereskovsky AV, Lavrov DV. 2017. Integrative taxonomic re-description of Halisarca magellanica and description of a new species of Halisarca (Porifera, Demospongiae) from Chilean Patagonia. Zootaxa 4208: 501-533.

Willenz P, Pomponi SA. 1996. A new deep sea coralline sponge from Turks and Caicos Islands: Willardia caicosensis gen. et sp. nov.(Demospongiae: Hadromerida). Bulletin de l'Institut royal des sciences naturelles de Belgique 66: 205-218.

Wörheide G, Dohrmann M, Erpenbeck D, Larroux C, Maldonado M, Voigt O, Borchiellini C, Lavrov DV. 2012. Deep phylogeny and evolution of sponges (phylum Porifera). Advances in Marine Biology 61: 1-78. 